\title{
Future Food in Utopia: A View from the Twenty-Second Century
}

\author{
Aline Ferreira \\ CETAPS/ Universidade de Aveiro
}

\begin{abstract}
The influential "Today \& Tomorrow" series of books published in London in the 1920s and 30s, which reflected on the future of science, technology and the arts, included a volume devoted to the future of food, Olga Hartley and C. F. Leyel's Lucullus; or, The Food of the Future (1926). The authors predict a number of scientific advances that will lead to synthetic food, with the Neo-Vegetarians evoking the possibility of plant consciousness, a topic which is receiving increased attention nowadays. With lab-produced meat having already been developed, and plant awareness driving further research into synthetic nutrition, these texts provide thoughtful speculation on the future of food and the urgent need to achieve a sustainable environment.
\end{abstract}

Keywords: synthetic food, neo-vegetarians, Olga Hartley, C. F. Leyel

Resumo: A influente série de livros "Today \& Tomorrow, publicada em Londres nos anos 20 e 30 do século passado, que desenvolveram uma reflexão sobre o futuro da ciência, tecnologia e das artes, incluía um volume dedicado ao futuro da comida, Lucullus; or, The Food of the Future (1926) da autoria de Olga Hartley e C. F. Leyel. As autoras imaginam vários avanços científicos que conduzirão à comida sintética e um grupo de NeoVegetarianos invoca mesmo a possível existência de uma consciência vegetal, um tópico que hoje em dia está a ser cada vez mais estudado. Enquanto carne produzida em laboratório já é uma realidade, a ideia que as plantas possuem um tipo de consciência impulsiona a investigação em nutrição sintética. Estes textos oferecem especulações produtivas sobre o futuro da alimentação, assim como em relação à necessidade urgente de promover a sustentabilidade do meio ambiente.

Palavras-chave: comida sintética, neo-vegetarianos, Olga Hartley, C. F. Leyel 
From the extraordinary overabundance of food in The Land of Cockaigne to feeding only on air in George Bernard Shaw's Farfetched Fables $(1948)^{1}$ - where people are what we would call breatharians, having eliminated meat and gradually all other types of food from their diet, surviving on water and air -, Utopias have always been centrally concerned with food. From communitarian meals and an emphasis on a return to the land and the values of an agrarian mode of life to synthetic food and chemical pills on the other end of the spectrum, standing for technology and a concentration on the efficient management of time, they can all be found in utopian or dystopian narratives, with a great degree of variation.

In the 1920s and 30s, a series of over one hundred books was published in London entitled "Today \& Tomorrow," which reflected on the future of science, technology and the arts. Predictably, it also included a volume devoted to the future of food, Olga Hartley and C. F. Leyel's Lucullus; or, The Food of the Future (1926). ${ }^{2}$ In it, the authors predict a number of scientific advances that will lead to synthetic food, with a sect called the Neo-Vegetarians evoking the possibility of plant consciousness, a topic which is receiving increased attention nowadays. Some of these books were tremendously influential, and indeed many of the topics discussed and visions laid out there found their way into fiction and also had an impact on scientific research and technological innovations. Hartley and Leyel's Lucullus; or, The Food of the Future will be examined here, testing how its predictions live up to the contemporary situation as far as food consumption and new food trends are concerned.

The first book in the "Today \& Tomorrow" series, and probably the most influential, by the geneticist J. B. S. Haldane, was called Daedalus or Science and the Future (1924). In it Haldane forecasts that chemistry will be used to produce food and that "many of our foodstuffs, including the proteins, we will probably build up from simpler sources such as coal and atmospheric nitrogen" (38). According to Haldane, "synthetic food will substitute the flower garden and the factory for the dunghill and the slaughterhouse, and make the city at last self-sufficient" (39). As he claims, "I should be inclined to allow 120 years, but not much more, before a completely satisfactory diet can be produced in this way on a 
commercial scale" (38), which will mean that "agriculture will become a luxury, and that mankind will be completely urbanized" (39).

Following in part the structure of J. B. S. Haldane's Daedalus, which is mentioned in Lucullus (39), where a student one hundred and fifty years into the future writes an essay about the state of science in the twentieth century, in Hartley and Leyel's book it is a fictional Professor Lucullus, F.R.S. [Fellow of the Royal Society] who delivers a lecture "upon some distantly future date" (43) around the middle of the twenty-first century. The historical Lucullus was a Roman general who lived in the 1st century BC and became famous for his gourmet banquets, having entertained, amongst many others, Cicero and Pompey as guests. ${ }^{3}$ Lucullus was also credited with introducing the apricot and a type of sweet cherry to Rome, as well as improving aquaculture capacities.

In this lecture, Prof Lucullus explains that in the "middle of the twentieth century the world became vegetarian" (43) under the impulse of the so-called Neo-Vegetarians, one of the "many curious religious sects that flourished about that time" (44). Under their influence, the "slaying of animals for food was categorized as a crime, as was the murder of human beings" (44-45). In order to achieve this goal, these Neo-Vegetarians "carried out a systematic campaign in the schools, and found it quite easy to make most children sentimental about animals when living, and not difficult to arouse in them a horror of devouring them when dead" (45). They also found it quite effortless to make them sentimental about "plants and flowers" (45). Indeed, as Prof Lucullus explains, their campaign was so successful that when the majority of the people had reached the stage of shuddering with disgust at the mere idea of eating such succulencies as lamb or roast duckling, there arose a hypersensitive minority who shrank with a greater refinement from the grossness of eating young carrots or green peas (46-47).

As a result of these new policies, sheep-breeding was halted, and towns were allowed to keep only a few specimens in their zoological gardens or parks, but purely for ornamental purposes. Even though people protested that imitation wool and leather were not as comfortable as the original products, scientists convinced them they were actually good for their health. 
Indeed, as Prof. Lucullus asserts, the scientists were instrumental in pushing through the Neo-Vegetarians' political agenda, since their invention of artificial feeding products provided the necessary nutrition for the people. According to Prof. Lucullus's narrative, the views advanced by the Neo-Vegetarians, coupled with a number of strikes carried out by the International Agricultural Workers Union, resulted in the halting of natural food production and harvesting for a whole year, a situation which in turn led to a demand for an alternative diet, which the scientists supplied in the shape of food created with recourse to alcohol, cellulose and bacteria, amongst other elements. Prof. Lucullus was naturally not impressed with this kind of dietary evolution and notes with satisfaction that the secret to the production of those synthetic products was lost.

This diet created by the scientists, who are said to have carried out their work at the end of the twentieth century without proper supervision and were allowed to perform any "experiments they liked, quite regardless of whether the results would be welcome or beneficial" (53), was very unpopular, making the people "discontented and irritable" (60). This diet was discontinued with the passing of the legislation of 2026, which gave rise to the "great reform movement" (62). From then on scientists were subjected to rigorous scrutiny by the Board of Censors.

\section{Synthetic Food}

Professor Lucullus also predicts a number of scientific advances that will lead to synthetic food, which will be invented in laboratories (36) and will be produced in industrial quantities. As he explains, these would be "not the patent foods we know, which are merely forms of wheat or cereals, or milk or malt, dried, preserved or put up in factories [...] but forms of food actually produced from inorganic materials" (37). Although the "dream of feeding the world on artificial flour, artificial fats, and synthetic foods, in general, has been a favourite phantasy of scientists for some generations past" (37), it is not yet ready to be implemented by them, Professor Lucullus explains. 
The fantasy of synthetic, chemical food and a meal in a pill, however, had already been discussed and fictionally dramatized in a number of $19^{\text {th }}$-century narratives. Some feminist writers speculated that the reduction of time women spent in the kitchen, or even the abolition of kitchens altogether replaced by communitarian ones, would go a long way towards improving women's position in society, freeing them to dedicate more time to pursue professional and personal interests.

On the occasion of the 1893 Chicago World Fair, which showcased technological progress in a wide variety of domains, several personalities were asked to imagine how the world would be in 1993. The Kansas representative, feminist writer, and political activist Mary Elizabeth Lease, who was amongst the first to contemplate the fantasy of a food pill, predicted that 1993 would bring

in condensed form the rich loam of the earth, the life force or germs now found in the heart of the corn, in the kernel of wheat, and in the luscious juice of the fruits. A small phial of this life from the fertile bosom of mother Earth will furnish men with substance for days. And thus the problems of cooks and cooking will be solved" (italics mine). ${ }^{4}$

Accordingly, Lease also forecasted the decrease of the amount of time women would need to spend performing household duties, and the consequent improvement of their status.

In an interview entitled "Foods in the Year 2000" (1894) the renowned French chemist Marcelin Berthelot speculated that chemistry would go a long way towards replacing agriculture by producing synthetic food. As Henry J. W. Dam reports, Berthelot believed that

[t]he epicure of the future is to dine upon artificial meat, artificial flour, and artificial vegetables [...] Wheat fields and corn fields are to disappear from the face of the earth, because flour and meat will no longer be grown, but made [...] Coal will no longer be dug, except perhaps with the object of transforming it into bread or meat. The engines of the great food factories will be driven, not by artificial combustion, but by the underlying heat of the globe. $(303)^{5}$ 
In addition, the future epicure will drink artificial wine and smoke artificial tobacco. In a preview of "Foods in the Year 2000", Berthelot was already thinking in terms of synthetic food, considering that beefsteak in pill form, produced from coal, might soon be available. As he observes:

We shall give you the same chemical food, chemically, digestively, and nutritively speaking. Its form will differ, because it will probably be a tablet. But it will be a tablet of any color and shape that is desired and will, I think, entirely satisfy the epicurean senses of the future. ${ }^{6}$

He predicts that synthetic food will substitute traditional food products, with the advantage of it being independent from nature's whims, allowing the countryside to recover from farmers' efforts to make it yield as much as possible, as well as being safer and free from potentially disease-causing bacteria. ${ }^{7}$ In Berthelot's utopian vision, with the gradual elimination of agriculture the "favored portions of the earth will become vast gardens, in which the human race will dwell amid a peace, a luxury, and an abundance recalling the Golden Age of legendary lore". 8

Berthelot's vision of synthetic food is also consonant with Mary E. Bradley Lane's in Mizora: A Prophecy (1889). In this highly developed all-women society, chemists created food from the elements and, as in the world described in Lucullus, during the time of the Vegetarians, they "kept no cattle, nor animals of any kind for food or labor" (20). Although they eat "chemically prepared meat" (18), fruit constitutes the main part of their diet, agriculture being a "lost art" (26). Indeed the only food they still grow is fruit, although their laboratories are now "striving to produce artificial fruit and vegetables that will satisfy the palate and be free from deleterious matter" (47). They believe their youthful appearance, robust health and "immunity from old age" (45) derive from the elimination of potentially harmful earthy matter from their food. Indeed, since "Science discovered that mysterious and complicated diseases often had their origin in adulterated food" (49), they have managed to eliminate them with judicious recourse to chemically prepared food, of which they are very proud for their healthy and gourmet qualities.

The writer and activist Charlotte Perkins Gilman has also considered how women's 
identification as the primary providers of food and cooking, activities that together with other household chores use most of their time and energy, has decisively contributed to their perceived subordinate position. In Women and Economics: A Study of the Economic Relation between Men and Women as a Factor in Social Evolution (1898), anticipating Virginia Woolf's main argument in A Room of One's Own (1928), Gilman defends the economic independence of women as indispensable to lifting them from their secondary status as citizens. As Gilman states: "the economic dependence of women has kept them back from their share in human progress. When women stand free as economic agents, they will lift and free their arrested functions, to the much better fulfilment of their duties as wives and mothers and to the vast improvement in health and happiness of the human race". ${ }^{9}$ Influenced in part by Edward Bellamy's vision of a prosperous, technologically advanced Boston in the year 2000, in Looking Backward: 2000-1887 (1888), where the cooking is done at public kitchens, Gilman advocates kitchenless houses or apartments and cooperative kitchens, as well as communitarian meals for those who so wished. ${ }^{10}$ She also defends the professionalization of domestic work, so that women would be freer to pursue their vocations.

In A Modern Utopia (1905), H. G. Wells also envisages a number of cooperative methods in terms of living conditions, with the utopian household as kitchenless. As he puts it, "The ordinary utopian would no more think of a special private kitchen for his dinner than he would think of a private flour mill or dairy farm" (148). Anna Bowman Dodd's The Republic of the Future: or, Socialism, a Reality (1887), by contrast, satirizes the notion that women resist spending long hours in the kitchen and envisages with revulsion and disgust the idea of food pellets which would be delivered from centralized larders by means of pneumatic tubes to kitchenless homes.

As Hartley and Leyel speculate, the "experiment of communal kitchens will almost certainly be tried; private enterprise has started them here and there, and apparently they pay; they will be extended. Then dwellings will be built without kitchens" (33). In this context, Hartley and Leyel are not enthusiastic and believe that food "cooked in large quantities may or may not be wholesome, but it is not so good as food cooked for a small 
number of people at a time" (33-34). In Lucullus, in turn, there was a time when their food was produced in "gigantic factories and distributed from large supply centres [...] Once a day the Government rations of food were delivered by the Post Office, neatly packed in cartons; each one was numbered, and returned empty in exchange for a full one" (64-65). As Prof. Lucullus puts it, "when the system worked it had certain merits, but sometimes it did not work" (65), mostly due to strikes, and chaos ensued. This centralized system, where the food supply was the monopoly of the Government, had many practical advantages, but since there was nothing else to eat people were totally dependent on the Government.

In Arthur Bird's Looking Forward; a Dream of the United States of the Americas in 1999 (1889) people actually "often dined on a pill - a small pellet which contained highly nutritious food" (Chapter XXI),11 a fantasy that clearly would not meet with Lucullus's favour.

\section{Chemical Banquets}

Lucullus's banquets with their gastronomic delights and their slow art of cookery could not be more different from the fantasy of chemical food in the form of pills, a technological innovation long contemplated by many science fiction writers. Indeed, pulp fiction is replete with tales considering the food of the future, with an emphasis on food pills and synthetic food. The fantasy of food pills might appear to be the ideal solution to save women, always associated with the preparation of meals, from a life partially spent in and around the kitchen.

Even though there is great excitement at the thought of developing a food pill, in most cases the general consensus is that after all it is better to return to real food and the much more complex, sensorial and overall fulfilling pleasures it can provide. Indeed, the banquets of the future where guests were served chemical food and food pills did not hold the same attraction as more traditional parties, and the nostalgia for real food soon became too strong.

Fred T. Jane (1865-1916), a prolific Victorian novelist, journalist, illustrator and 
naval author, provides a representative vision of one of those banquets in his illustration of A Dinner Party A.D. 2000. Menu of Chemical Foods (The Pall Mall Magazine, May 1895, p. 96), one of seven drawings entitled "Guesses at Futurity". In a lavish setting, reminiscent of an Egyptian temple, waiters are depicted with food trays, predictably the Chemical Foods mentioned in the title, a vision that presumably would be very distasteful to Prof. Lucullus.

According to Winston Churchill in "Fifty Years Hence" (1931), "Synthetic food will, of course, also be used in the future. Nor need the pleasures of the table be banished. That gloomy Utopia of tabloid meals need never be invaded. The new foods will from the outset be practically indistinguishable from the natural products". ${ }^{12}$ Unlike Churchill, however, Olga Hartley and C. F. Leyel prophesied that synthetic foods, though practicable/viable, would be unpalatable and the fashion, eventually, discarded.

\section{Plant Consciousness}

The idea of plant awareness and consciousness is not a new one, with some Victorian botanists considering this hypothesis seriously. In his book on plant physiology An Essay on the Probability of Sensation in Vegetables (1811), James Perchard Tupper believes that there are instances that "strongly indicate the presence of sensation" (28) in plants. Drawing on Darwin's book The Movements and Habits of Climbing Plants (1875), W. Lauder Lindsay, a physician and botanist, argued that "some form or degree of Consciousness exists in plants" $(1876,521)$, suggesting that certain behaviours can be seen as instances of "choice", "selection" and "preference" (1876, 525).13 As Lindsay further observes, signs of "Attachment to place or things, which are obvious in the case of many climbers, may, perhaps, in other plants explain much that the botanist, horticulturist, arboriculturist, floriculturist, or agriculturist cannot otherwise satisfactorily account for". In addition, significantly, Lindsay claims that "Plants exhibit occasionally individuality, and even eccentricity, for which we cannot account, any more than we can for similar peculiarities in man or other animals" $(1876,523)$. 
Professor Lucullus also describes how the Neo-Vegetarians evoke the possibility of plant consciousness. Indeed, the Vegetarians believed that, following a pantheistic world view, "every little blossom that blows enjoys the air it breathes" (46) and they went on to "publish pamphlets to prove the cruelty of cutting off young cauliflowers in their prime, and wrote lyrical laments over lettuces" (46). As the author of a famous poem on lettuces claimed in a lyrical vein, since lettuces, "if allowed to flower and seed and find selfexpression in the full development of all their powers, lost some of the qualities for which they are valued as salads, it was the custom to massacre them when they were young and tender" (47), the poem being passionately against the "brutality of the proceeding" (47).

In Erewhon (1872), Samuel Butler had also written about the rights of plants, admittedly in a satirical vein. The chapter on "Rights of Animals, by an Erewhonian prophet" is followed by another on "Rights of Vegetables," where a Botany Professor associated animal and vegetable with the faculty of adaptation to a certain environment. According to the Professor, "vegetables are only animals under another name. ${ }^{14}$ Thus, he provocatively went on to argue,

if it was sinful to kill and eat animals, it was not less sinful to do the like by vegetables or their seeds. None such [...] should be eaten, save what had died a natural death, such as fruit that was lying on the ground and about to rot, or cabbage-leaves that had turned yellow in late autumn. These and other like garbage he declared to be the only food that might be eaten with a clear conscience. Even so the eater must plant the pips of any apples or pears that he may have eaten, or any plum-stones, cherrystones, and the like, or he would come near to incurring the guilt of infanticide. ${ }^{15}$

However, as the narrator in Erewhon concludes, after much soul-searching, "[e]ven the Puritans after a vain attempt to subsist on a kind of jam made of apples and yellow cabbage leaves, succumbed to the inevitable, and resigned themselves to a diet of roast beef and mutton, with all the usual adjuncts of a modern dinner-table".

Bearing a striking resemblance to the Erewhonian Professor's arguments, the NeoVegetarians in Lucullus regarded ripe fruit as admissible as a dietary item but only if "gathered from the ground after the trees had no further use for it" (47), a controversial 
matter since they also insisted that the tree limbs should be "spared the mutilation of the pruning knife" (47-48). The whole dietary issue became even more difficult to negotiate when the Neo-Vegetarians disagreed over the diets of plants, with one sect maintaining that plants were not "strict enough in their own diet" (48) while other plants were seen as having "gross tastes that turn a poet pale" (48). Prof Lucullus explains that people were "as careful over feeding the plants that nourish us as we are over feeding the animals that we eat" (76).

As Aaron Xavier Fellmeth argues, drawing on Samuel Butler, biologically speaking a plant "needs to thrive and reproduce just as much as human beings do. Inert matter such as stones, mountains, and watercourses have no such teleology and are excluded from the argument" (55). Considering the argument that defends a "universal human duty towards plants of some kind" (56), Fellmeth states that it seems very unlikely that the duty "would be of sufficient moral weight to justify even a minimal legal duty against gratuitously killing specific plants or disabling their reproductive ability" (55-56). Indeed, according to Fellmeth, the act of showing "excessive moral concern for plants would underprotect human and animal interests, because all humans and animals rely directly or indirectly on killing plants for sustenance" (56). However, as he suggests, the argument for a "duty to respect the human interests in the safety, health, and reproduction of plants is much stronger" (56). Significantly, Prof. Lucullus had already called attention to the concerns some people expressed about how plants fed themselves, and how their diets should be supervised in terms of their impact on human health.

Indeed, plant awareness and cooperation have been widely established by scientists such as Jeffrey T. Nealon (2015) and Peter Wohlleben (2016). As Barbara J. King observes, engaging with Peter Wohlleben's The Hidden Life of Trees, "Trees growing in undisturbed forests communicate in olfactory, visual and electrical ways," facts that have been clearly established by science. ${ }^{16}$ As Anil Ananthaswamy in related vein notes, scientists

are finding that plants have a sophisticated awareness of their environment and of each other, and can communicate what they sense. There is also evidence that plants have memory, can integrate massive amounts of information and maybe pay attention. Some botanists argue that they are 
intelligent beings, with a "neurobiology" all of their own. There's even tentative talk of plant consciousness. (2014)

According to Natasha Myers, "plant sensing is a widely studied phenomenon, and falls under the purview of mainstream plant science in molecular biology, biochemistry, plant physiology, and ecology" $(2015,35)$. Interestingly, areas being explored by different scientists include "anticipatory" behaviours in plants (36). As Myers states, sunflowers "not only track the sun during the day, they also move through the night in order to be in the right place to greet the sun the next morning" (36). Myers argues that plants have "incredible sensory dexterities, and that they can make sense of and actively intervene in their worlds" (36; italics in the original). Indeed, Myers talks about "the plant turn," a "recent swerve in attention to the fascinating lives of plants among philosophers, anthropologists, popular science writers, and their widely distributed, electronicallymediated publics" (40).

Botanist Matthew Hall, in turn, in his book Plants as Persons: a philosophical botany (2011), urges us to behave more ethically towards plants, arguing they should be included within the purview of our moral responsibilities. Indeed, a sizable number of books and articles reflecting on plant consciousness has recently appeared, including philosopher Michael Marder's Plant thinking: a philosophy of vegetal life (2013), anthropologist Eduardo Kohn's How forests think: toward an anthropology beyond the human (2013), scientist Craig Holdrege's Thinking like a plant: a living science for life (2013), amongst many others that remind us that plants do indeed possess forms of sentience, instinct, and can adapt to the environment and communicate.

\section{Conclusion}

Olga Hartley and C. F. Leyel's Lucullus; or, The Food of the Future is as relevant nowadays as when it first came out in 1926, predicting a number of trends that are indeed garnering increased awareness today, such as the importance of a gradual adoption of a 
vegetarian diet in terms of the health of the population and the upkeep of a sustainable environment. Synthetic food is also gaining ground, in particular lab-produced meat which will be on supermarket shelves soon, with immense benefits to the environment, provided that people adhere to it. ${ }^{17}$ Their calling attention to plant consciousness or awareness of their environment and how they react to it is also very topical and relevant in terms of contemporary plant consciousness studies.

Lucullus is a book centrally concerned with the problems of feeding the world in a time of crisis, as seen from the vantage point of a post-First World War era, as well as with future developments that might positively or negatively impact food production and distribution. As Barbara Santich notes, Hartley and Lyell's forecasts about the future of food and society were predicated on a "thorough study of contemporary trends in food production and trade, food preparation and consumption" (221).

In a gentle satirical vein, Hartley and Leyel satirize the exaggerations of new food trends, such as vegetarianism carried to extremes, synthetic food and the concept of a meal in a pill, 18 that, when tested, would be found to be wanting in the future world described by Prof. Lucullus. "Will the Lucullus of the future be a toothless valetudinarian dining off a tabloid of artificial protein, chemical lemonade, and an injection of strychnine?" (40-41). After all, how could a meal in a pill or artificially grown food satisfy a gourmet and food connoisseur like Prof. Lucullus? It can be safely imagined that the slow food movement and an emphasis on organic produce would be more to his taste and meet with his approval.

Indeed, the only problem in this future world is, according to Prof. Lucullus, gluttony, which can lead to "terrible deterioration both of physical health and moral character" (77). To obviate this state of affairs, there is a movement that wishes to make "overeating a statutory offence" (77). It is also suggested that Professors of the Culinary Art, who are probably too highly considered in Prof. Lucullus's view, are partly to blame for the widespread overeating in this society. ${ }^{19}$

In her book Looking for Flavour (1996) Barbara Santich, after briefly analyzing Hartley and Leyel's Lucullus, transports Prof Lucullus even further into the twenty-second century. In this future scenario, vertical farms and hydroponics were widespread, 
developments that will be increasingly part of our contemporary world. Following the Roman general's efforts at improving aquaculture facilities, the new Prof. Lucullus explains that in this future society "all fruits and vegetables were grown hydroponically, in vast, centrally located, glass-walled skyscrapers. The system was highly efficient, since there was no need to harvest the vegetables [...]. Households had vegetables at the peak of their freshness, harvested to order when required" (267). Indeed, Hartley and Leyel were greatly in favour of utilizing all the available resources, including growing edible plants in the gardens and city areas, and Prof. Lucullus is very critical of what he considered as a wasteful use of land where non-edible flowers and plants were cultivated solely for their scent and aesthetic qualities.

Prof. Lucullus described the $20^{\text {th }}$ century as a "wasteful age" (74), where wind power and water were not profitably used. By contrast, in the twenty-first century portrayed by him, through harnessing the energy of the tides, not only can they light and warm the earth but also get three harvests during the year, since they can "replenish the fertility of the soil as soon as one crop has exhausted it" (63). Theirs is no longer a wasteful age, but one of which Prof. Lucullus can be proud, which contemporary scientists and politicians might do well to imitate.

\section{NOTES}

${ }^{1}$ George Bernard Shaw became a vegetarian due to his conviction that a man "fed on whiskey and dead bodies cannot do the finest work of which he is capable" ("Nine Answers", 1923). Quoted in Allen, Brigid, 327.

2 Hilda Leyel (1880-1957), the author of Lucullus; or, The Food of the Future, was the founder of the Society of Herbalists in England, in 1927, and an expert on herbalism. Amongst her books can be cited The Gentle Art of Cookery (1925) and Elixirs of Life (1948), a work on herbalism. Olga Hartley, who collaborated with Leyel in the writing of Lucullus and The Gentle Art of Cookery, was a journalist and suffragist.

3 As Rhiannon Evans notes, the name Lucullus and "Lucullan" are "still indicators of a lavish lifestyle, particularly regarding dining habits" (202). A cookery book by "Lucullus," Food for the Gods, a clear reference to H. G. Wells's The Food of the Gods (1904), was published in 1931. 
${ }^{4}$ Quoted in Adelle Wessel, "Between Alimentary Products and the Art of Cooking: The Industrialisation of Eating at the World Fairs - 1888/1893", 115.

${ }^{5}$ As Richard Faulk observes, Marcellin Berthelot's "Foods in the Year 2000" can be described as a "syntheticfood manifesto" $(2015,131)$.

${ }^{6}$ Quoted in Faulk, in Food in the USA: A Reader, 64.

${ }^{7}$ This gradual elimination of agriculture is also envisaged by J. B. S. Haldane in Daedalus.

${ }^{8}$ Quoted in Faulk, in Food in the USA: A Reader, 65.

9 <http://digital.library.upenn.edu/women/gilman/economics/economics.html> (consulted on 12/05/2017).

${ }^{10}$ In Meals to Come: A History of the Future of Food (2006) Belasco provides an overview of communitarian practices of feeding in $19^{\text {th }}$-century utopian narratives.

$11<$ https://archive.org/stream/lookingforwarddr00bird/lookingforwarddr00bird_djvu.txt> (consulted on 14/5/2017).

12 The Strand Magazine, December 1931.

${ }^{13}$ See also Lara Pauline Karpenko, Shalyn Rae Claggett, eds., 2016.

14" <http://www.gutenberg.org/files/1906/1906-h/1906-h.htm> (consulted on 15/05/2017).

${ }^{15}$ According to Mel Chen "It is possible to conceive of something like the 'affect' of a vegetable, wherein both the vegetable's receptivity to other affects and its ability to affect outside of itself, as well as its own animating principle, its capacity to animate itself, become viable considerations" $(2012,4)$.

16 "Trees, hugging." TLS, 14/12/2016.

${ }^{17}$ Synthetic, lab-produced meat is a recurring trope in utopian and science fiction narratives. In the meantime, synthetic meat, grown in the lab from stem cells of an animal like a cow and then coaxed to develop into strips of muscle with recourse to tissue engineering techniques was prepared and served as a hamburger by scientists from Maastricht University in the Netherlands, led by Prof. Mark Post, in 2013.

${ }^{18}$ For an overview of the origins and development of the concept of a meal in a pill see Warren Belasco (2002).

19 The contemporary popularity of cooking programmes, Masterchef competitions and of Chefs themselves bears an intriguing similarity with the situation described by Prof. Lucullus.

N. 36 - 06/ 2017 | 43-61 - ISSN 2183-2242 | http:/dx.doi.org/10.21747/21832242/litcomp36a2 


\section{Works cited}

Allen, Brigid, ed. (1995), Food. An Oxford Anthology, Oxford, Oxford University Press.

Ananthaswamy, Anil. (2014) "Root intelligence: Plants can think, feel and learn", New Scientist, 3 December 2014.

Belasco, Warren (2002), "Future Notes: The Meal-in-a-Pill", in Food in the USA. A Reader, New York, Routledge: 59-72.

-- (2006), Meals to Come. A History of the Future of Food, Berkeley, California, University of California Press.

Bellamy, Edward (2009), Looking Backward. 2000-1887, Oxford, Oxford University Press.

Bird, Arthur (1889), Looking Forward. A Dream of the United States of the Americas in 1999, Utica, NY, L. C. Childs \& Son.

Butler, Samuel, (2006) Erewhon, London, Penguin Classics, <http://www.gutenberg.org/files/1906/1906-h/1906-h.htm> (consulted on 12/05/2017). Chen, Mel Y. (2012), Animacies. Biopolitics, Racial Mattering, and Queer Affect, Durham, NC, Duke University Press.

Churchill, Winston / Steven Spurrier (1931), Fifty years hence. Strand Magazine, December, 82 (492).

Dam, Henry J. W. (1894), "Foods in the Year 2000. Professor Berthelot's Theory That Chemistry Will Displace Agriculture", McClure's Magazine, September, 303-312.

Dodd, Anna Bowman (1887), The Republic of the Future. Or, Socialism, a Reality, New York, Cassell \& Company.

Evans, Rhiannon (2008), Utopia Antiqua. Readings of the Golden Age and Decline at Rome, London / New York, Routledge.

Faulk, Richard (2015), The Next Big Thing. A History of the Boom-or-Bust Moments That 
Shaped the Modern World, San Francisco, Zest Books.

Fellmeth, Aaron Xavier (2016), Paradigms of International Human Rights Law, Oxford, Oxford University Press.

Gilman, Charlotte Perkins (2002), Women and Economics. A Study of the Economic Relation between Men and Women as a Factor in Social Evolution, Lanham, Maryland, AltaMira Press.

Haldane, J. B. S. (1924), Daedalus or Science and the Future, New York, E. P. Dutton \& Company.

Hall, Matthew (2011), Plants as persons. A philosophical botany, Albany, NY, State University of New York Press.

Hartley, Olga / C. F. Leyel (1925), The Gentle Art of Cookery, London, Chatto \& Windus.

-- (1926), Lucullus. Or, The Food of the Future, London, Kegan Paul.

Holdrege, Craig (2013), Thinking like a Plant. A Living Science for Life, Barrington, MA, Lindisfarne Books.

Jane, Fred T. (1895), “A Dinner Party A.D. 2000. Menu of Chemical Foods”. The Pall Mall Magazine, May, 96.

Karpenko, Lara Pauline / Shalyn Rae Claggett, eds. (2016), Strange Science: Investigating the Limits of Knowledge in the Victorian Age, University of Michigan Press.

King, Barbara J. (2016), “Trees, hugging”, TLS, 14/12/2016. <http://www.thetls.co.uk/articles/public/trees-hugging/> (consulted on 14/01/2017).

Kohn, Eduardo (2013), How Forests Think. Toward an Anthropology beyond the Human, Berkeley / Los Angeles, University of California Press.

Lane, Mary E. Bradley (1889), Mizora. A Prophecy, New York, G. W. Gillingham.

Leyel, Hilda (1948), Elixirs of Life, London, Kegan Paul.

Lindsay, W. Lauder (1876), “Mind in Plants,” British Journal of Psychiatry 21, 96, January, 513-532. 
"Lucullus" (1931), Food for the Gods, London: Grant Richards.

Marder, Michael (2013), Plant Thinking. A Philosophy of Vegetal Life, Columbia University Press.

Myers, Natasha (2015), “Conversations on Plant Sensing”, NatureCulture 03, 35-66, 35.

Santich, Barbara (1996), Looking for Flavour, Kent Town, Australia, Wakefield Press.

Shaw, George Bernard, (1995), "Nine Answers", In Food: An Oxford Anthology, Oxford, Oxford University Press, 327.

-- (1992), Farfetched Fables, in Last Plays, London, Penguin Books.

Tupper, James Perchard (1811), An Essay on the Probability of Sensation in Vegetables, London, White, Cochrane, and Company.

Wells, H. G. (2010), The Food of the Gods, London, Gollancz.

-- (2005), A Modern Utopia, London, Penguin Books.

Wessel, Adelle (2010), "Between Alimentary Products and the Art of Cooking. The Industrialisation of Eating at the World Fairs - 1888/1893", In Consuming Culture in the Long Nineteenth Century. Narratives of Consumption, 1700-1900, Lanham, Maryland, Rowman \& Littlefield, 107-123.

Woolf, Virginia (2002), A Room of One's Own, London, Penguin. 
Aline Ferreira did her First Degree, in English and German, at the University of Oporto, and completed her PhD at the University of London (Birkbeck College) in 1988, with a Thesis on D. H. Lawrence and E. M. Forster. She has been teaching since 1987 at the University of Aveiro, where she has been an Associate Professor since 1996. Her courses include British Literature of the 19th, 20th and 21st centuries, Cultural Studies, Literature and Science and Utopian Studies at both undergraduate and postgraduate level, including PhD courses. Her main areas of academic interest include women's studies, interart and intermedial studies, in particular the intersections between literature and science as well as literature and the visual arts, psychoanalysis and utopian studies. Her book I Am the Other: Literary Negotiations of Human Cloning was published by Greenwood Press in 2005. Recent publications comprise articles on feminist utopias, eugenics, biotechnological dystopias and bio art. She is now working on a book provisionally entitled: The Sexual Politics of the Artificial Womb: Fictional and Visual Representations. 